\title{
DELIMITATION OF FREEDOM OF CONTRACT PRINCIPLE AND JUDGE'S CORRECTIVE FUNCTION IN ASSESSING THE PARTIES' POSITIONS ON AN AGREEMENT
}

\author{
M. Natsir Asnawi* dan Edi Hudiata** \\ Judges of Banjarbaru Religious Court \\ Jalan Trikora Nomor 4 Kota Banjarbaru, Kalimantan Selatan 70714
}

\begin{abstract}
The principle of freedom of contract established for much types of contract. This principle concerned on how parties state their mind freely into the contract clauses. The primordial concept of freedom of contract was reduced based on Indonesian judiciary practice. This normative research of law tries to analyse the concept alteration of meaning and implementation of freedom of contract in Indonesian Judiciary practice. The Supreme Court of Indonesia through its precedent provides broader authority to the Judges in order to supervise and remedy the unbalance stand of parties on a contract they state which causes one or more considerations cannot be or make difficulties to perform. The result of this research show us that freedom of contract principle is confined by proportionality, appropriateness, and justice principles toward parties in a contract stated.
\end{abstract}

Keywords: freedom of contract, judges, precedent, justice.

\section{Intisari}

Asas kebebasan berkontrak merupakan asas yang melandasi berbagai bentuk kontrak yang ada. Asas ini menekankan pada pernyataan kehendak secara bebas dalam kontrak-kontrak yang dibuat. Pemahaman mengenai asas kebebasan berkontrak telah direduksi berdasarkan praksis peradilan di Indonesia. Penelitian ini merupakan penelitian normatif yang menelaah pergeseran pemikiran mengenai makna dan implementasi asas kebebasan berkontrak dalam praksis hukum kontrak Indonesia. Yurisprudensi Mahkamah Agung memberikan kewenangan lebih luas kepada Hakim untuk meneliti dan mengoreksi ketidakseimbangan kedudukan para pihak dalam kontrak yang menyebabkan suatu prestasi dalam kontrak tidak dapat atau sulit untuk dilaksanakan. Hasil penelitian menunjukkan bahwa asas kebebasan berkontrak dibatasi oleh prinsip-prinsip proporsionalitas, kepatutan, dan keadilan bagi para pihak dalam suatu kontrak.

Kata Kunci: kebebasan berkontrak, hakim, yurisprudensi, keadilan.

\section{Pokok Muatan}

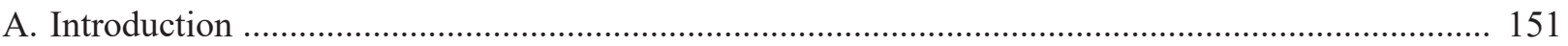

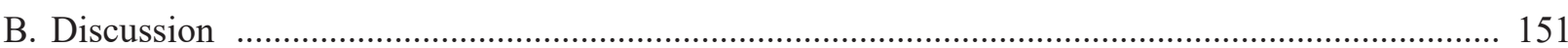

1. The Principle of Freedom of a Contract on an Agreement ....................................................... 151

2. Judge's Corrective Function in The Parties Contract ................................................................. 158

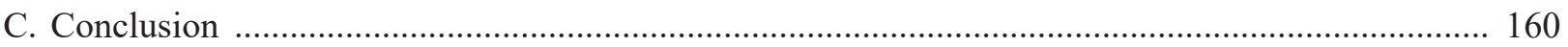

Email correspondence: natsirasnawi@rocketmail.com.

Email correspondence: edihudiata31122012@gmail.com. 


\section{A. Introduction}

The general principle of the contract law is that every party free to make a contract with a content and form agreed. The freedom of contract (contract vrijheid) gives discretion to every individual to makes a contract with another party. This principle becomes the basic of all forms of contract concluded by the parties.

The principle of freedom of contract emphasizes that the parties according to the law are free to determine the matters that will be mentioned in the contract. Likewise, regarding the form of the contract, the parties are free to choose whether it is in written or unwritten. The implementation of the principle of freedom of contract is guided by several things, namely: fulfilling the validity requirements of an agreement, does not violate any regulation and the applicable customary norm, and implemented with good faith. ${ }^{1}$ The meaning of the freedom of contract is thus understood as an "accountable" freedom, namely a freedom that does not violate the legal principles and appropriateness.

The openness of Book III of Indonesian Civil Code (KUHPerdata) is a direct implication of the existence of freedom of contract principle. Because of such openness, the law gives a space at large to the parties to formulate the clauses on the contract which represent the rights and obligations (considerations) of each party. The formulation of such contract clauses, except as a reflection of each party's position on the contract, sometimes creates problem of the imbalance of rights and obligation of the contract. It is no surprise if then in several contracts we found in practice are reflecting that there are so many obligations burdened to one party where the other party only burdens a small number of responsibilities. Consequently, there is a superior party and an inferior party in a contract.

In fact, the principle of freedom of contract indicates a balance between the rights and obligations of the parties. It thus raises a comprehension that in the case of a contract is not reflecting a balance between the rights and obligations of the parties; a corrective function is needed to restructure and rebalance the positions of the parties. Who is supposed to undertake or perform this correction function? Is it the parties themselves or the Judge because of his office permits him to perform the corrective function? In what regard and to what extend the corrective function can be implemented into a contract? These are the problems that will become the topic of this research.

Based on such background explanation, the writers formulate two problems as follow: (1) In what case the freedom of contract becomes limited?; (2) Does Judge have the authority to correcting the positions of the parties on a contract?

\section{B. Discussion}

1. The Principle of Freedom of a Contract on an Agreement

a. The Definition of Agreement (Contract)

The term of agreement (verbinetenissen) is often associated with a contract or an obligation (perikatan/overenkomst). Even though they are different in terms of their etymology meanings, however in the operational structure, whenever an agreement is mentioned, its connotation refers to a contract or an obligation (perikatan). This can be understood as the agreement itself is the reason or the basis of a contract. This writing is not purposed to polarize both terms, therefore, whenever the term of contract or obligation (perikatan) is mentioned, vice versa the term of agreement is thus implied.

Agreement (perjanjian) in English is called as a contract. The term of contract itself according to Black's Law Dictionary is defined as follows: "a promissory agreement between two or more persons that creates, modifies, or destroys a legal relation. ${ }^{2}$ Such definition emphasizes that an agreement 
(contract) is a promissory agreement between two parties or more. Consent (persetujuan) which is agreed conveys legal consequence in the commencement, change, or cessation of a legal relationship. This definition more stresses on the effect of consent (persetujuan).

In general, the basic reference to define an agreement is Article 1313 of KUHPerdata. According to such article, an agreement is: "consent (persetujuan) is an action in which one person or more binds himself to another person or more." The definition of the abovementioned Article 1313 is criticized by Subekti. Such definition obscures the essential meaning of the agreement in such a way that Article 1313 defines an agreement as a unilateral action although in fact generally, an agreement is a reciprocal action from the parties who bind themselves to it. ${ }^{3}$

Still, in regard to the normative definition, an agreement in Islamic Law is called as aqd or akad. Article 20 paragraph (1) Indonesian Supreme Court Regulation No 2 of 2008 regarding Compilation of Sharia Economic Law stipulates: "Akad is a consent in an agreement between two parties or more to perform and/or not perform certain legal action."

An agreement according to Riduan Syahrini is a legal relationship between two parties in the field of assets where one of the parties acts as a creditor who reserves the right to certain obligation (prestasi) and the other party as debtor is obliged to fulfil such obligation (prestasi) $)^{5}$. Salim HS define an agreement as a legal relationship between one legal subject to another legal subject in the field of assets, where one of the legal subjects reserves the right over an obligation and the other legal subject is obliged to perform such obligation in accordance with consent between them. ${ }^{6}$

M. Yahya Harahap defines an agreement as a relationship of property law or assets between two persons (parties) or more who gives the power of the right to a party to obtain a performance and at once oblige the other party to perform such performance Such definition describes that on an agreement, there are several construction elements, namely 1) legal relationship; 2) right; and 3) obligation (prestasi). Legal relationship on an agreement is a desirable legal relationship by its parties and not a legal relationship which born by itself or born because of the law. For instance, the legal relationship of the family properties. On the legal relationship of the family properties, the legal relationship between the children and the assets of their parents automatically arises, as has been regulated in inheritance law whether it is the Islamic inheritance law or the civil inheritance law. ${ }^{7}$

The legal relationship which born from an agreement is a desirable legal relationship. The existence of such legal relationship is preceded with a legal action (rechtshandeling). The legal relationship in an agreement is a reciprocal relationship between the right and obligation of each party. ${ }^{8}$ The writers call it as a reciprocal relationship on an agreement where a right of a party becomes an obligation for the other, vice versa.

Suharnoko, 2008, Hukum Perjanjian: Teori dan Analisa Kasus, Kencana, Jakarta, p. 119.

Pusat Pengkajian Hukum Islam dan Masyarakat Madani, 2009, Kompilasi Hukum Ekonomi Syariah (Edisi Revisi), Prenada Media Group, Jakarta, p. 15

Riduan Syahrani, 2006, Seluk Beluk dan Asas-Asas Hukum Perdata, Alumni, Bandung, p. 196

Salim HS, et.al, 2008, Perancangan Kontrak \& Memorandum of Understanding (MoU), Sinar Grafika, Jakarta, p. 9.

M. Yahya Harahap, 1986, Segi-Segi Hukum Perjanjian, Alumni, Bandung, p. 6.

Ibid., p. 7. 
b. The Principles of The Law of Agreement

\section{1) The Personel Principle}

The personnel principle can be found on the stipulations of Article 1315 of KUHPerdata which stipulates that "in general, there is nobody can bind on behalf of himself or raise a request to enact a promise except for himself." Specifically, such stipulation refers to the authority to act as an individual for/and on behalf of himself. ${ }^{9}$

\section{2) The Principle of Consensuality}

The substance of the principle of consensuality is an agreement which made verbally between two parties or more has bound and therefore brings an obligation to one of the parties or more on such agreement after the parties reach a consent.

\section{3) The Principle of Freedom of Contract}

According to the history, the freedom of contract is a reflection of the development of free trade concept pioneered by Adam Smith through his theory of classic economic. He bases his ideas to the nature law, the same law that becomes the basis of Jeremi Bentham's thoughts known as the Utilitarianism. Utilitarianism and the theory of classic economy laisez faire are regarded completing each other, and both initiate the concept of liberal individualistic. ${ }^{10}$

The freedom of contract in English literature is also known as the
"Party Autonomy"11, or the "Liberty of Contract." The term freedom of contract is generally used rather than the rest. The principle of freedom of contract is a universal principle, meaning that it is generally applied in all States.

According to the Civil Law applicable in Indonesia, the freedom of contract can be concluded from the stipulation under Article 1338 paragraph (1) KUHPerdata which stipulates that "all of the contracts (agreements) which are concluded legally, applies as a law for those who make it" Subekti. By stressing on the wording "all," from such article, we can read a statement for the people that we are allowed to make an agreement which is in the form of anything and contains anything (or about everything), and such agreement will bind those who make it, similar to law. ${ }^{12}$

Mariam Darus Badrul Zaman states that the freedom of contract is one of the important principles of the contract law. Such freedom is a manifestation of the free will, a portrayal of the human rights. A similar opinion is also addressed by Abdul Kadir Muhammad who said that this principle has a meaning that the people may conclude an agreement about anything, although it has not been or is not regulated under the laws. This principle is often referred as The Freedom of Making Contract. ${ }^{13}$

\footnotetext{
Kartini Muljadi and Gunawan Widjaja, 2003, Perikatan yang Lahir dari Perjanjian, Rajawali Pers, Jakarta, p.15.

Sutan Remy Sjahdaeni, 1993, Kebebasan Berkontrak Dan Perlindungan Yang Seimbang Bagi Para Pihak Dalam Perjanjian Kredit Bank, Institut Bankir Indonesia, Jakarta, p. 17.

1 Matthias E. Storme, "Freedom of Contract: Mandatory and Non-Mandatory Rules in European Contract Law", Juridica Internasional, Vol. XI, 2006, p. 37.

Subekti, 1976, Hukum Perjanjian, Alumni, Bandung, p. 47.

Abdulkadir, Muhammad, 2010, Hukum Perdata Indonesia, Citra Aditya Bakti, Bandung, p. 20.
} 
The principle of freedom of contract regulates stipulation that essentially the parties can make an agreement or consent which can create any obligation as long as such compulsory duty is not prohibited. The stipulation of Article 1337 says " cause is prohibited if it is prohibited by law, or if it violates morality or public order." Such stipulation gives a description that basically all agreements can be concluded and performed by every person. An agreement which is prohibited is an agreement that contains obligation or duty on one of the parties which violates the law or morality ${ }^{14}$.

Such principle contained on the stipulation under Article 1338 paragraph (1) KUHPerdata which says "All agreements made legally apply as the law to those who conclude it."

This principle of freedom of contract grants freedom to the parties to: conclude and not conclude an agreement, conclude an agreement with anybody, determine the content of the agreement, its performance, and requirements, and determine the form of the agreement, whether it is written or verbal. ${ }^{15}$

The principle of freedom of contract at the time of its birth in 17 and 18 centuries had a strong working power, meaning that such freedom worked without being limited by the people's sense of justice or state intervention. This created injustice for the parties who did not have balanced position. ${ }^{16}$
In its further development, this principle of freedom of contract gets a better limitation, whether it is of the law, court judgment, and extra legal standard which all of them finally arrive at the inclination of the compulsion of agreement's content and performance to the appropriateness norms. ${ }^{17}$

\section{4) The Principle of Pacta Sunt} Servanda

This principle is regulated under Article 1338 paragraph (1) KUHPerdata which stipulates that "All agreements made legally apply as the law to those who conclude it." According to such stipulation, it can be understood that an agreement that has been concluded consciously and based on consent from each of the party acts as a law (regulation) that binds each of the parties who makes such agreement.

\section{5) The Principle of Justice}

The principle of justice is in substance a principle that applies in all legal field, without exception to the contract law which has a civil nature. The principle of justice emphasizes the importance of balance between right and obligation of the parties on an agreement. This principle becomes the basis of the act of contract performing. Justice on an agreement gives a legitimation for the parties to perform the contract with a good faith (te goeder trouw). In a contract, it is not allowed for a party to become more superior or inferior. Instead, a contract must represent free will of the parties on balanced positions. Several court judgments show that 
from all principles in the contract law, the principle of justice is the main principle and becomes a patron for the Judge to assess the validity of an agreement with all of its legal consequences (rechtsgevolg).

\section{c. Breach of Contract (Wanprestasi)}

Breach of Contract (wanprestasi) is a condition where the parties or one of the parties do not fulfil the obligation as has been stipulated in the agreement ${ }^{18}$. In simple words, the breach of contract (wanprestasi) is a negligence from the parties or one of the parties to perform his obligations (prestasi) as has been mentioned in the articles of the agreement that has been agreed.

The abovementioned negligence or the non-fulfilment of obligation is a conditio sine qua non for a disqualification of the party who breaches the contract. Article 1234 KUHPerdata stipulates: "Obligation is purposed to provide something, to do something or not to do something."

\section{d. The Enforceability of The Principle of Freedom of Contract}

The parties who will bind themselves to an agreement (contract) are free to convey their will. The statement of parties' will is stated on the clauses which are proposed and agreed to be clauses of the contract. This statement of the will essentially covers two things, namely the obligation (consideration) and the rights. The obligation is the matters in the form of duties (prestasi) that are burdened to one of the parties or both. This obligation eventually gives rise to the rights. Hence, in the contractual concept, there is a saying that an obligation of one party procreates the right of the other.

The formulation of the clauses of the contract is principally based on the abovementioned statement of the will. However, the practice of the statement of the will which later becomes a clause in the parties' contract does not always reflect a balance positions of the parties on the contract. One party might be burdened with too much obligation while in contrast with the other party, the rights given to him might be minimal. This kind of practice is often found in financing practices between financial institution as a creditor and customer as debtor. Indeed, it should be admitted that this kind of practice remains and is not disputed by the parties, particularly the customer as the debtor who often becomes the inferior. However, this practice for scientific concept needs to be studied further, especially regarding the implementation of the principle of freedom of contract on such financing contract.

As a patron of tradition for countries that embrace common law system, the contract practice in the United States, has placed the freedom of contract as a principle which is limited by various things related to the appropriateness or other value standards (whether it is legal value or non-legal). Therefore, the freedom of contract cannot go against the current values. The Chief Justice Charles Hughes once stated:

Freedom of contract is a qualified, and not an absolute, right. There is no absolute freedom to contract as one chooses. Liberty implies the absence of arbitrary restraint -not immunity from reasonable regulations. ${ }^{19}$

The freedom of contract cannot be interpreted as absolute freedom. The freedom of contract is a principle that implies the freedom for each to conclude a contract with another party which is not allowed to contain anything manipulative and arbitrary. 
The freedom of contract, therefore, can be understood as a freedom with responsibility and full awareness that each person has fair rights and obligations and it has to be respected and maintained by other people or the other party. Therefore, it can be understood that the repulsion from the responsibility of the loss of another party with an excuse of freedom of contract is an act that cannot be justified. An act which is in contradiction with the law, intended to manipulate other party involved in the contract to obtain certain advantage, cannot be justified.

The freedom of contract also means that nobody is immune from reasonable regulations. Freedom of contract is freedom with responsibility and consistent with the meaning and purpose of the stipulation of the law. From here can be drawn the continuity of the importance of Judge's role in maintaining and harmonizing the principle of freedom of contract as a norm together with its application to the parties' contract.

The actual value contained in the delimitation of freedom of contract is balancing the rights and obligations of the parties to a contract. It can be imagined if the parties are given unlimited freedom to determine the title of the rights and obligations upon themselves and another party, it will then lead to far and wide disparities and the rise of conflicts. The contract is no longer becomes a tool to fulfil and improve the standard of living but as a tool to take control of the other party. It thus fits to what has been said by David P. Weber:

freedom of contract is subject to some limitation; however, the general right of an individual to contractually obligate himself and receive corresponding obligations in return is so pervasive and necessary for our society as to make it a fundamental right, and as such, to be entitled to a significantly higher level of protection. ${ }^{20}$

One of the interesting cases related to the importance further study regarding the implementation of the freedom of contract principle can be seen in Singgih v. Paul Boernadi Koesnadinata which has been decided by the Supreme Court in cassation level through Judgement No. 1076 K/ Pdt/1996 dated 09 March 2000²1. Case started when Paul (Respondent) borrowed money from Singgih (Claimant) in the amount of Rp 350.000.000,- (three hundred and fifty million rupiahs) which was stipulated under the statement of debt acknowledgement with a clause that saying that the Respondent is obliged to repay the loan at the latest by the date of 10 May 1990 in such amount added by $2.5 \%$ monthly interest rate that had been firstly paid on 10 September 1998 . However, in the subsequent months the Respondent was no longer make any payment towards the interest as has been agreed; thus, the Claimant considered the Respondent breached the contract (wanprestasi). The Claimant then filed this case to the Court and had been decided in cassation level.

The Supreme Court in its decision granted the claim of the Claimant to declare that the Respondent had breached the contract and punish him to pay compensation. However, the Supreme Court concluded that the agreed rate of monthly interest, $2.5 \%$, even though had been agreed by the parties, needed to be adjusted to the interest rate that was used in the government banks, namely

20 David P. Weber, "Restricting the Freedom of Contract: A Fundamental Prohibition" ,Yale Human Rights and Development Journal, Vol. 16, No.1, 2013, p. 58 .

21 See Mahkamah Agung RI, 2009, Himpunan Putusan yang Telah Berkekuatan Hukum Tetap dalam Bidang Perdata dan Perdata Khusus Mahkamah Agung Republik Indonesia (Jilid 1), Mahkamah Agung, Jakarta, p. 180. 
$18 \%$ annually, calculated from the date when the claim was registered until the moment when the Respondent paid all the debts or the moment when the judgment was executed. The Respondent was punished to pay the $18 \%$ interest rate annually instead of $30 \%$ as had been agreed by the parties.

The debtor (Respondent) was still classified as breaching the contract since he had only paid one month interest which was agreed. However, even though he was considered breaching the contract, the Supreme Court corrected the rate of the interest to be adjusted with the average interest rate applied to the government banks.

The rate of the interest agreed by the Claimant and Respondent was $2.5 \%$ monthly or $30 \%$ annually. Such interest exceeded the average of government bank interest which was ranging in $18 \%$ rate annually. It could be seen from here that the Supreme Court took a decision that freedom of contract which was manifested on the inclusion of a clause regarding the interest of the debt could not exceed the average general interest rate.

The Supreme Court stressed that the freedom of contract, even though it became the basis of a contract, it could not be justified if such freedom raised an obligation which was too big to one of the parties than other obligations. Freedom of contract becomes limited when it is confronted with the aspect of justice and appropriateness.

Such aspect of justice means the parties are supposed to be placed in the mutually beneficial positions, whether it is regarding the enjoyment of an object or the allocation of the agreed contract risk. On the other hand, the aspect of appropriateness is related with the reasonableness of obligation imposition to the actual ability of the parties.

Perhaps the parties have agreed to a contract, but it cannot be denied that there is a chance of inappropriate clause in such contract. In abovementioned case, the imposition of interest rate up until 30\% annually is generally incriminating and potentially inducing payment difficulties of the debtor.

Referring to such case, the implementation of the principle of freedom of contract is apparently relative. Meaning that the statement of the will of the parties is required to notice several things. First, the freedom of contract is directly related to the aspect of justice. The freedom of contract reflected on the clauses of the contract shall pay attention to the balance between the rights and obligations of each party. The balance of the rights and obligations does not mean identical and equal an sich, but the balance here means a balance that pays attention to the position or stands and the proportion of the rights and obligations which are supposed to be on each of the parties.

Second, the freedom of contract is limited by general norms, such as appropriateness, morality and other general norms. In the context of the case as mentioned earlier, for instance, the freedom to determine the rate of the interest is limited by general standard of interest rate on government banks. Therefore, to determine the rate of the interest, it is compulsory to notice the maximum value of such loan interest rate. Hence, it can be understood that the freedom of contract which is related with such general norms, should be understood as a freedom with responsibility. The parties are however bound to the moral values.

Third, the freedom of contract is also limited by the principle of appropriateness in imposing obligations on another party. Even though the parties are freed to raise their will about the obligation that will be burdened to another party, he must keep considering the actual ability of the party that will receive the obligation. Appropriateness, therefore, 
becomes one of the measurements that limits the implementation of the freedom of contract. These burdensome clauses in legal practice are often disputed and referring to the jurisprudence experiences in Indonesia, these onerous clauses are often declared as null and void and do not have legal binding force to the parties.

\section{Judge's Corrective Function in The Parties}

\section{Contract}

\section{a. Judge's Authority}

A judge has a fundamental duty in judiciary field to accept, assess, decide and settle every single case which is submitted to him. Therefore, the judge is the principal executor in the implementation of judicial authorities. The existence of a judge can be seen through his decisions.

It is indeed uneasy for a judge to make an ideal decision. The purpose of an ideal decision according to Gustav Radbruch is a decision that contains idee des recht, which covers three elements, namely justice (gerechtigkeit), legal certainty (rechtsicherheit) and utility (zwechtmassigkeit) ${ }^{22}$.

Thomas Aquinas states that the essence of law is justice; therefore, the law shall contain justice. The law which is uncertain is not the law itself. Bismar Siregar, the former Chief Justice also has similar opinion.

For Bismar, a judge has the duty to interpret the law so that the law functions as a living law since a judge is not merely upholding formal regulations but should find a living law in the middle of society. ${ }^{23}$ Further Bismar states that justice is more important than the certainty of law, hence the primary duty of a Judge is to find the meaning or essence from a regulation or legal norm instead of a mere legal procedure. ${ }^{24}$

Another jurist, Sudikno Mertokusumo states that such three elements, wherever possible should exist in a proportional judgment, namely legal certainty (rechtssicherheit), utility (zweckmassigkeit), and justice (gerechtigekeit). ${ }^{25}$ That is the ideal form. However, practically speaking, it rarely exists a judgment which contains those three elements proportionally. If it is not possible to construct their existence proportionally, at least those three factors would be existing in the judgment.

In case there is a conflict between justice and legal certainty as well as utility, Sudikno recommends the Judge to prioritize justice. Justice according to Plato ${ }^{26}$, "Is the supreme virtue which harmonizes all other virtues." Further, Greek philosopher views justice as a purpose which continuous and constant to give every person his right, "justice is the continuous and continual purpose which gives to everyone his own."

In Islamic terminology, it is also found in the literature that obliges Muslims to act justly in settling a case. In Surah An-Nisa verse 58, it is mentioned "And when you judge between people to judge with justice." Further in verse 135 of the same Surah, it is stated, "O you who have believed, be persistently standing firm in justice, $[\ldots]$ ".

Because justice is the primary purpose, hence in the head of judgment it is stipulated, "For The Sake Of Justice In Belief To The Almighty God" - not for the sake of legal certainty or utility. In the matter of law, a judge is considered to have known (ius curia novit); therefore there is no reason for a

\footnotetext{
22 Sudikno Mertokusumo, 2011, Teori Hukum, hlm. 23 dan Bambang Sutiyoso, 2012, Metode Penemuan Hukum Upaya Mewujudkan Hukum yang Pasti dan Berkeadilan, UII Press, Yogyakarta, p. 8.

Bambang Sutiyoso, Op. cit., p. 17.

Faisal, 2010, Menerobos Positivisme Hukum, Rangkang, Yogyakarta, p. 5-6.

Sudikno Mertokusumo, Op. cit., p. 92.

Bambang Sutiyoso, Op.cit., p. 15.
} 
judge to reject or does not know the law. In reasoning his judgment, a judge shall because of his office to complete legal reasoning that is not presented by the parties. ${ }^{27}$

If a judge operates the procedure of legal finding properly and structured, thus it can be obtained a judgment that fulfils the sense of justice, utility and legal certainty. Thus, it is the essence of the duty and responsibility of a judge by giving justice to the parties (justitiabelen).

\section{b. Judge's Corrective Function in Jurisprudence}

To analyse the corrective function of a judge, there are several judgments in cassation level that give a room for the judge to correcting the parties' agreement which is considered injustice, namely Judgment No. $1076 \mathrm{~K} / \mathrm{Pdt} / 1996$ dated 09 March $2000^{28}$ and Judgment No. 3641 K/Pdt/2001 dated 11 September 2002.

In Judgment No. $1076 \mathrm{~K} / \mathrm{Pdt} / 1996$, there is Judges reasoning that the interest rate which was settled $30 \%$ annually, even though has been agreed by the parties, is needed to be adjusted with the interest rate that is applicable to the government banks, namely $18 \%$ annually.

The Supreme Court in this decision classified the Respondent had breached the contract (wanprestasi) because he only paid one month interest which was agreed. However, even though classified as (wanprestasi), Supreme Court corrected the rate of the interest which was burdened to adjust with the average interest rate of the government banks. Here there is a correcting function performed by Supreme Court.

Specifically, Supreme Court corrected the interest rate agreed by the Claimant and the Respondent, $2.5 \%$ monthly or $30 \%$ annually. Such rate was far exceeding the average of the government banks' interest rate which was around $18 \%$ annually.

On the other hand, in the Judgment No. 3641 K/Pdt/2001, Supreme Court strictly nullified a contract No. 41 and 41 which were concluded by the parties on 29 October 1997, as well as the Deed No. 31 which was made by the parties on 26 November 1997. The reasoning of the Supreme Court inter alia, that the principle of freedom of contract (contract making) is not absolute, meaning that in certain situation, judge has the authority through the interpretation of the law to study and assess as well as declare, that the positions of the parties in a contract are in some way imbalance; thus one of the parties is unfree to raise his will, as if the contract concluded unilaterally.

The system of Indonesian contract law has an open nature. Therefore, when a contract is concluded, it is not only KUHPerdata and Adat Law which are binding but also other living norms that live among the people in conformity with appropriateness, justice, humanity such as the abuse of situation/ opportunity and or the abuse of economy that is applicable contiguously and continuously thus it is a unity, thus the legal norms purposed, have an impact that can be used as an agent of change to the stipulations that have been agreed on such contract.

Because of such consent is made in a situation where the parties are imbalance, Supreme Court decided that there is an abuse of situation or opportunity where the Cassation Applicant as one of the parties of such contracts is not in free position to raise his will, therefore the Supreme Court decided that such contracts should be nullified.

This Judgment No. $3641 \mathrm{~K} / \mathrm{Pdt} / 2001$ 
becomes the jurisprudence of the Supreme Court. Such judgment delivers an outstanding legal proposition regarding the meaning of the freedom of contract and the authority of the Judge: "in regard to the principle of freedom of contract, judge has the power to study and declare that the positions of the parties are in imbalance situation; thus, one of the parties is considered unfree to raise his will".

The essence of the legal proposition on such decision is at least categorized into two things. First, the freedom of contract is a principle which is limited by the values of justice and reasonableness toward the distribution of the rights and obligations of the parties in a contract. Second, the limitation towards the freedom of the parties in stating their will is purposed to be an effort to protect the parties from the arbitrariness of the other party in the contract.

\section{Conclusion}

Based on the analysis of the discussion above, it can be concluded things as follows:

1. The principle of freedom of contract has a limitation nature. Although the parties have freedom to raise their will and mention certain clauses, the statement of the will stipulated on such clauses is no allowed to be in contrary with the principles of appropriateness, justice, and proportionality. The purpose of the delimitation of freedom of contract is two, namely, first, the freedom of contract is a principle which is limited by the values of justice and reasonableness toward the distribution of the rights and obligations of the parties in a contract. Second, the delimitation towards the freedom of the parties in stating their will is purposed to be an effort to protect the parties from the arbitrariness of another party.

2. A judge has authority to correct a contract or the clause of a contract if a contract or a clause in a contract places the parties into imbalance or disproportional position. The corrective function of the Judge can be in the form of a nullification of a clause or correcting certain clause in conformity with the purpose of creating balance and proportionality of the parties in the contract.

\section{REFERENCES}

\section{A. Books}

Fuady, Munir, 2014, Konsep Hukum Perdata, Rajawali Pers, Jakarta.

Black, Henry Campbell, 1968, Black's Law Dictionary, Fourth Edition, West Publishing Co., Minnesota.

Suharnoko, 2008, Hukum Perjanjian: Teori dan Analisa Kasus, Kencana, Jakarta.

Pusat Pengkajian Hukum Islam dan Masyarakat Madani, 2009, Kompilasi Hukum Ekonomi Syariah (Edisi Revisi), 2009, Prenada Media Group, Jakarta.

Syahrani, Riduan, 2006, Seluk Beluk dan Asas-Asas Hukum Perdata, Alumni, Bandung.

Khairandy, Ridwan, 2004, Iktikad baik Dalam
Kebebasan Berkontrak. Program Pascasarjana Fakultas Hukum Universitas Indonesia, Jakarta.

HS, Salim, et.al, 2008, Perancangan Kontrak \& Memorandum of Understanding (MoU), Sinar Grafika, Jakarta

Harahap, M. Yahya, 1986, Segi-Segi Hukum Perjanjian, Alumni, Bandung.

Muljadi, Kartini and Gunawan Widjaja, 2003, Perikatan yang Lahir dari Perjanjian, Rajawali Pers, Jakarta.

Sjahdaeni, SutanRemy, 1993, Kebebasan Berkontrak Dan Perlindungan Yang Seimbang Bagi Para Pihak Dalam Perjanjian Kredit Bank, Institut Bankir Indonesia, Jakarta. 
Subekti, 1976, Hukum Perjanjian, Alumni, Rangkang, Yogyakarta.

Bandung.

Abdulkadir, Muhammad, 2010, Hukum Perdata Indonesia, Citra Aditya Bakti, Bandung.

Salim HS, 2005, Hukum Kontrak, Teori dan Teknik Penyusunan Kontrak, Sinar Grafika, Jakarta.

Mahkamah Agung RI, 2009, Himpunan Putusan yang Telah Berkekuatan Hukum Tetap dalam Bidang Perdata dan Perdata Khusus Mahkamah Agung Republik Indonesia (Jilid 1), Mahkamah Agung, Jakarta.

Mertokusumo, Sudikno, 2011, Teori Hukum, hlm. 23 dan Bambang Sutiyoso, 2012, Metode Penemuan Hukum Upaya Mewujudkan Hukum yang Pasti dan Berkeadilan, UII Press, Yogyakarta.

Faisal, 2010, Menerobos Positivisme Hukum,

\section{B. Articles Journal}

Storme, Matthias E., "Freedom of Contract: Mandatory and Non-Mandatory Rules in European Contract Law", Juridica Internasional, Vol. XI, 2006.

Weber, David P., "Restricting the Freedom of Contract: A Fundamental Prohibition", Yale Human Rights and Development Journal, Vol. 16, No.1, 2013.

\section{Others}

US Supreme Court Reasoning in the case of Chicago, Burlington \& Quincy R. Co. v. McGuire, 219 U.S. 549 (1911). 